\title{
PENGEMBANGAN E-LIBRARY DALAM MENINGKATKAN PELAYANAN DI PERPUSTAKAAN IAIN BATUSANGKAR
}

\author{
Tri Yuliani \\ Pegawai IAIN Batusangkar \\ Jln. Sudirman No. 137 Kubu Rajo, Lima Kaum Batusangkar \\ E-mail: triyuliani3314@gmail.com
}

\begin{abstract}
Information and communication technology is the most important part of IAIN Batusangkar library. The development of e-library or digital library in IAIN Batusangkar library is a solution to overcome various phenomena such as individual phenomenon, the distance location, social environment demanding fast and accurate information needs without having to visit the library and data collection requirement that can be accessed at any time. Responding to this phenomenon, IAIN Batusangkar Library developed a computerized automation system directed to improve the service process to the user library with good quality and speed, as well as to improve the effectiveness and efficiency of library management. The approach used is internet-based visualization. Digital Library is built by using Zi-shof e-library application of e-campus model. In the Digital Library is available a variety of collection of books, theses, journals, and research reports. The development of E-Library can be accessed either by students or not through the campus application of IAIN Batusangkar with the access library port http: //pustaka.iainbatusangkar. It answered a challenge and an important goal for an institution to develope the library in the future.
\end{abstract}

Keywords: Digital Library, e-library, Information Technology, IAIN Batusangkar.

\section{PENDAHULUAN}

Dengembangan Informasi and
Communication (ICT) yang amat cepat dan luas turut membawa dan mempengaruhi suatu lembaga dalam berbagai bidang tidak terkecuali pada perpustakaan. Undang-undang no 43 tahun 2007 secara jelas menyebutkan adanya pemanfaatan TIK dalam perpustakaan seperti pada pasal ayat 19 ayat 2 yang berbunyi "pengembangan perpustakaan dilakukan berdasarkan karakteristik fungsi dan tujuan serta dilakukan sesuai dengan kebutuhan pemustaka dan masyarakat dengan memanfaatkan teknologi informasi dan komunikasi". Semua itu menjadi dasar bahwa pengembangan dan pengelolaan perpustakaan mau tidak mau harus memperhatikan adanya implementasi ICT di dalamnya. Pengembangan sistem ICT juga tidak terlepas pada perpustakaan IAIN Batusangkar.

Saat ini perpustakaan IAIN Batusangkar adalah salah satu perpustakaan telah melaksanakan sistem implementasi ICT pada pelayanannya dan merupakan 
perpustakaan pertama yang telah memakai sistem otomasi di Kabupaten Tanah Datar.

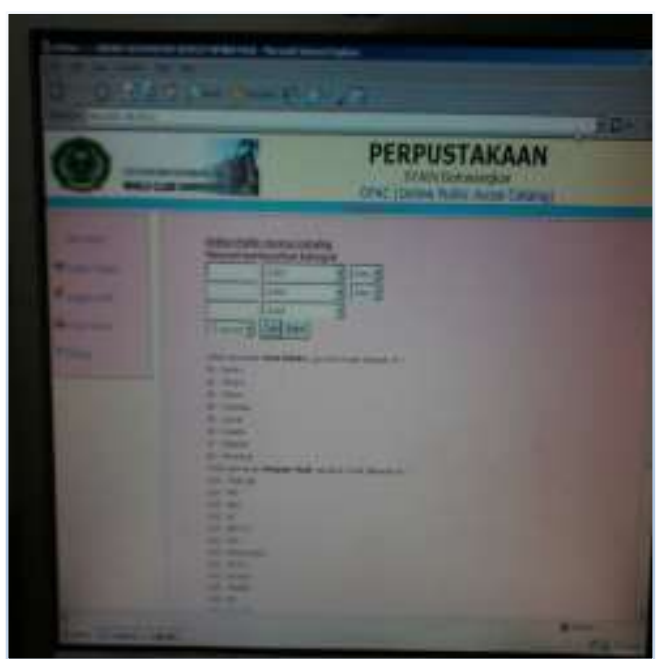

Gambar Sistem Informasi E- Library lama Model Otomasi Perpustakaan IAIN Batusangkar

Perkembangan sistem ICT pada perpustakaan IAIN Batusangkar yang mengarah pada perpustakaan berbasis digital belum sepenuhnya berjalan dengan optimal masih banyak kekurangan yang ditemukan. Faktanya masih banyak kondisi yang berbanding terbalik seperti yang diharapkan dalam undang-undang tersebut. Pada penelitian sebelumnya tentang perpustakaan digital, paradigma, konsep dan teknologi informasi yang digunakan Imam Yuadi (2007:1) bahwa library initiative menggambarkan perpustakaan digital sebagai lingkungan yang bersama-sama memberi koleksi, pelayanan dan manusia untuk menunjang kreasi, diseminasi, penggunaan dan pelestarian data, informasi dan pengetahuan.
Kelemahan dari sistem tersebut belum tersentralisasi datang secara baik, sehingga masih mengalami kesulitan dan mencari data, sehingga memerlukan pengembangan baru untuk menambah beberapa fitur dari perpustakaan digital sehingga lebih mudah dalam pencarian data sesuai dengan kebutuhan. Selain itu penelitian sebelumnya belum begitu terintegrasi dengan ICT sehingga masih bersifat semi digital.

Data dilapangan menunjukkan bahwa meskipun memakai sistem otomasi perpustakaan, masih ditemukan kesulitan pengguna dalam menemukan koleksi buku yang dibutuhkannya. Seperti ungkap salah seorang mahasiswa PAI Andri pada tanggal 11 Oktober 2016 "saya terkadang sulit menemukan sumber tugas yang diberikan dosen saya".

Hal ini memberikan gambaran bahwa kesulitan menemukan koleksi buku yang dibutuhkan menunjukkan kekurangan perpustakaan dalam memberikan layanan pecarian koleksi bahan pustaka. Faktor individu seperti phobia yang ada pada pengguna saat melihat koleksi perpustakaan yang banyak dan rak yang belum tersusun rapi sehingga menjadikan pengguna malas berkunjung ke perpust Selain itu, kesulitan yang dihadapi oleh pengelolah atau manajemen perpustakaan, diantaranya: tidak bisa mengetahui apakah dengan nama dan nim mahasiswa pada saat sedang berkunjung berapa lama di perpustakaan tersebut karena buku 
tamu anggota masih bersifat manual dan kurangnya sumber daya manusia (SDM) yang bisa menangani sendiri digital library yang khusus memonitor dan merawat digital library. akaan itu sendiri.

Pelayanan perpustakaan sudah menjalankan sistem komputerisasi namun masih ditemukan kekurangan lain seperi faktor sosial yang menginginkan kecepatan informasi tanpa harus melalui sistem pelayanan yang rumit dan interaksi peminjaman koleksi yang terkadang antri terlalu lama.

Kondisi lingkungan perpus-
takaan yang banyak diminati pengunjung baik dari dalam maupun dari luar lingkungan memberikan tantangan tersendiri bagi perpustakaan untuk menciptakan pelayanan yang efektif dan efisien yang mempu dimanfaatkan oleh pengguna. Selain itu kondili lingkungan yang sulit dijangkau oleh pengguna selain mahasiswa sekitar IAIN Batusangkar, seperti lingkungan, jarak dan bangunan perpustakaan yang jauh bagi pengguna yang kuliah sambil bekerja, ataupun yang lokasi tempat tinggal yang jauh dari bangunan perpustakaan harus memakan waktu dan biaya jika harus datang sendiri keperpustakaan untuk mencari koleksi pustaka.

Ma'aruf (2009:3) mengatakan Realita yang terjadi pada masyarakat umum, penilaian terhadap media informasi yang paling disorot adalah sistem atau software-nya ulas
Syamsudin (2013:2). Gambaran fenomena diatas menjadi alasan penulis untuk melihat pengembangan sistem e-library dalam rangka meningkatkan pelayanan kepada pengguna pustaka pada perpustakaan IAIN Batusangkar Pemanfaatan (ICT) dalam mengelola, memanage atau menjalankan operasional perpustakaan dapat meningkatkan kualitas layanannya yakni dari segi kecepatan dan kualitas informasi yang diberikan. Perkembangan dan penerapan ICT dapat diukur dengan telah digunakannya sebagai system informasi manajemen perpustakaan dan pengembangan e-library dengan perpustakaan digital. Perpustaakaan sebagai tempat dimana informasi dikelola tentu saja akan selalu dipengaruhi oleh perkembangan ICT ini.

Pemanfaatan adalah sesuatu yang sudah ada atau sudah tercipta, dimanfaatkan oleh yang membutuhkan. Pengertian pemanfaatan adalah aktivitas menggunakan proses dan sumber belajar, Seels and Richey (1994).

Setiap perkembangan ICT hendaknya diikuti dengan praktek/ implementasi yang dapat dikembangkan di perpustakaan. Penerapan ICT ini sangat mendukung pelayanan kepada pengguna yang saat ini sangat membutuhkan informasi yang cepat. 
1. Sistem Manajemen Perpustakaan

Sistem perpustakaan yang ada tidak terlepas dari prinsip manajemen. Menurut Koontz dan o'Donnel dalam Komalasari (2014:1.40) prinsip manajemen terbagi atas:

a. Planning, yaitu menentukan sasaran yang ingin dicapai.

Perencanaan perpustakaan berkaitan dengan rencana kebutuhan SDM berdasarkan aktivitas perpustakaan yaitu berdasarkan jumlah mahasiswa.

b. Organizing, penetapan struktur peran melalui penentuan aktivitas yang dibutuhkan untuk mencapai tujuan.

c. Staffing, adalah pengisian jabatan dalam organisasi dengan cara pengidentifikasian kebutuhan tenaga , merekruit karyawan.

d. Directing, memimpin dan mengawasi orang-orang bawahan atau sub ordinat.

e. Controlling, upaya sistematis untuk menetapkan standar prestasi pada sasaran perencanaan, merancang sistem umpan balik.

Secara umum fungsi manajemen perpustakaan dapat digambarkan dalam bagan seperti berikut:

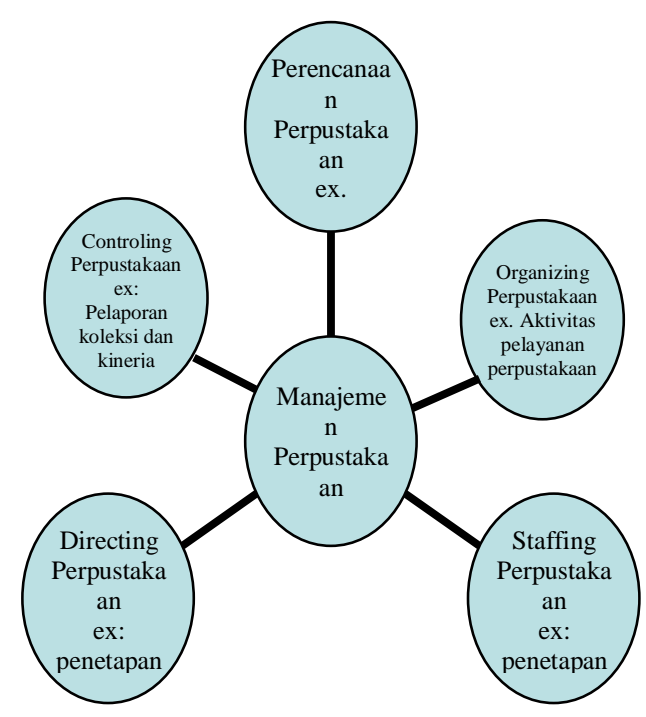

Bagan Fungsi Manajemen

\section{Pengembangan E-library dengan Sistem Perpustakaan Digital}

Ide pertama kali muncul sebagai dasar konsep perpustakaan digital pada bulan Juli tahun 1945 oleh Vannevar Bush. Dia mengeluhkan cara penyimpanan informasi manual yang dapat menghambat akses penelitian yang sudah dipublikasikan. Untuk itu, Bush mengajukan gagasan untuk membuat catatan dan perpustakaan pribadi (untuk buku, rekaman/dokumentasi, dan komunikasi) yang termekanisasi, Purtini (2007).

Sejak awal 1980-an fungsifungsi perpustakaan telah diotomasi melalui perangkat komputer, namun hanya di lembaga-lembaga besar mengingat biaya investasi yang sangat besar. Misalnya pada Library of Congress di Amerika yang telah mengimplementasikan sistem tampilan dengan dokumen elektronik 
(electronic document imaging systems) demi kepentingan penelitian dan operasional perpustakaan. Dilihat dari pengguna, komputer bukanlah bagian dari fasilitas manajemen perpustakaan melainkan hanya pelayanan untuk digunakan staf perpustakaan.

Teknologi informasi dan komunikasi (TIK) memberikan peranan penting dalam melakukan sistem digital dan memberikan informasi secara akurat dan cepat. Siswadi (2009: 5) mengatakan bahwa teknologi yang semakin terdistribusi dan juga World Wide Web mengarah pada akses informasi secara demokratis.

Siswadi mengutip salah satu pandangan Lewis yang mengatakan bahwa perpustakaan dapat berperan dalam komunikasi ilmiah dengan melakukan digitalisasi koleksi khusus. Setiap lembaga dimana perpustakaan tersebut memiliki publikasi lokal yang tidak diterbitkan secara komersial. Dengan cara digitalisasi jenis koleksi khusus tersebut seperti artikel jurnal, makalah, prosiding dan lain-lain menjadi kekayaan informasi yang dapat diakses oleh masyarakat pemustaka lebih luas.

Jie Sun dan Bao-Zhong Yuan (2012:12) mengatakan, perpustakaan digital adalah "Colletion of digital object (text, video, audio) along with method for access and retrieval, \{as far as user are concernd\} and also for selection, organization, and maintenance". "Koleksi digital yang terdiri objek (teks, video dan audio) yang menggunakan metode untuk akses selama pengguna fokus dan juga untuk seleksi, organisasi dan memperbaiki. Vivid Rizqy (2014: 149) mengemukakan bahwa perpustakaan sebagai salah satu "aktor"yang berperan dalam pengumpulan, pengolahan dan pendistribusian informasi mau tidak mau harus berhadapan dengan apa yang dinamakan teknologi informasi.

Susanto (2010:17) mengatakan Perpustakaan digital adalah perpustakaan modern yang sudah menggunakan sistem otomasi dalam operasionalnya serta mempunyai koleksi bahan pustaka sebagian besar dalam bentuk format digital yang disimpan dalam arsitektur komputerisasi dan bisa diakses melalui komputer.

Digital Library atau perpustakaan digital adalah suatu perpustakaan yang mampu menyimpan data baik itu buku (tulisan), gambar, suara dalam bentuk file elektronik dengan baik dan mendistribusikannya dengan menggunakan protokol elektronik melalui jaringan komputer, Cleveland (1997)

Menurut Sismanto (2008:150) gagasan perpustakaan digital diikuti Kantor Kementerian Riset dan Teknologi dengan program Perpustakaan Digital yang diarahkan memberi kemudahan akses dokumentasi data ilmiah dan teknologi dalam bentuk digital secara terpadu dan lebih dinamis. 


\section{Digital Libraries Initiative} pada tahun 1994 dalam bidang digitalisasi dokumen dan pembangunan sistem untuk dokumen digital. Perpustakaan digital (digital library atau electronic library) adalah perpustakaan yang mempunyai koleksi bahan pustaka sebagian besar dalam bentuk format digital yang disimpan dalam arsitektur komputerisasi dan bisa diakses melalui komputer. Perputakaan digital merupakan sebuah sistem perpustakaan yang menggunakan elektronik dalam menyampaikan informasi dari sumber yang dimiliki dan menggabungkan koleksi-koleksi, layanan dan sumber daya manusia untuk mendukung penuh siklus penciptaan, diseminasi, pemanfaatan dan penyimpanan data informasi, serta pengetahuan dalam format digital yang telah dievaluasi, diatur, diarsip dan disimpan, melalui komputer stand alone, intranet, atau internet.

Penerapan sistem perpustakaan digital ini akan sangat membantu pustakawan dan para pengguna perpustakaan. Bagi pustakawan, sistem ini akan sangat membantu pekerjaan mereka melalui fungsifungsi otomasi yang tersedia, sehingga proses pengelolaan perpustakaan akan menjadi efektif dan efisien.

Koleksi dari perpustakaan digital adalah dokumen digital umumnya terdiri dari lima jenis yaitu teks, gambar, suara, gambar bergerak (video), dan grafik. Bentuk teks digital akan memudahkan proses manipulasi data, ukuran datanya lebih kecil karena data terformat dalam bentuk SGML (Standard Generalized Markup Language). Begitu juga jenis data digital yang lain (gambar, suara, gambar bergerak, dan multimedia) akan lebih mudah dimodifikasi sesuai dengan kebutuhan, serta memudahkan dalam proses penelusuran.

SGML merupakan kumpulan dari kode-kode yang menyatukan komponen-komponen (judul, formula, paragraf diagram dan lainlain). Dokumen SGML dapat disimpan lebih efisien dan dapat diperoleh kembali secara keseluruhan ataupun per komponen. Lebih penting lagi, SGML melindungi bentuk atau tampilan dari sebuah dokumen, dan dapat dilihat (preview) sebelum dicetak.

Beberapa defenisi diatas menggambarkan pengembangan perpustakaan menggunakan sistem digital ini adalah salah satu jalan untuk meningkatkan pelayanan kepada pengguna dengan memberikan akses kemudahan yang efektif dan efisien.

2.1 Dasar Pemikiran Perpustakaan Digital

Menurut Gatot Subrata (2009:6) ada beberapa hal yang mendasari pemikiran tentang perlu dilakukannya digitalisasi perpustakaan adalah sebagai berikut:
a. Perkembangan teknologi informasi di Komputer semakin 
membuka peluang-peluang baru bagi pengembangan teknologi informasi perpustakaan yang murah dan mudah diimplementasikan oleh erpustakaan di Indonesia.

b. Perpustakaan merupakan lembaga yang edukatif, informatif, preventif dan rekreatif yang diterjemahkan sebagai bagian aktifitas ilmiah, tempat penelitian, tempat pencarian data/ informasi yang otentik, tempat menyimpan, tempat penyelenggaraan seminar dan diskusi ilmiah, tempat rekreasi edukatif dan kontemplatif bagi masyarakat luas.

c. Dengan fasilitas digitasi perpustakaan, maka koleksikoleksi yang ada dapat dibaca/dimanfaatkan oleh masyarakat luas baik di Indoensia, maupun dunia Internasional

d. Volume pekerjaan perpustakaan yang akan mengelola puluhan ribu hingga ratusan ribu, bahkan bisa jutaan koleksi, dengan layanan mencakup masyarakat (peserta didik, tenaga kependidikan, dan masyarakat luas), sehingga perlu didukung dengan sistem otomasi yang futuristik (punya jangkauan kedepan), sehingga selalu dapat mempertahanan layanan yang prima.

Standar perpustakaan digital pada umumnya hampir sama dengan standar perpustakaan non digital, seperti yang tercantum dalam pasal 11 UU No. 43 Tahun 2007 tentang Perpustakaan (standar koleksi, standar sarana prasarana, standar pelayanan, standar tenaga perpustakaan, standar penyelenggaraan, standar pengelolaan), namun lebih ditekankan pada koleksi dan pelayanan digitalnya. Standar khusus untuk perpustakaan digital ini secara angka masih belum ditentukan dengan jelas, sehingga diperlukan rapat kerja khusus untuk menentukan standarisasinya. Beberapa standar yang perlu mendapat perhatian adalah sebagai berikut:

a) Standarisasi six-ware (sudah dibahas pada bagian design perpustakan digital), yaitu : 1) Standarisasi software, 2) Standarisasi hardware, 3) Standarisasi netware, 4) Standarisasi dataware, 5) Standarisasi brainware, dan 6) Standarisasi environmentware

b) Standarisasi koleksi digital yang meliputi: 1) Rasio antara jumlah koleksi digital dengan jumlah pengguna potensial, contoh: $700 / 1000=70 \%, 2$ ) Rasio antara koleksi teks digital dengan total koleksi digital, 3) Rasio antara koleksi gambar digital dengan total koleksi digital, 4) Rasio antarakoleksi suara digital dengan total koleksi digital, 5) Rasio antara koleksi video dengan total koleksi digital, 6) Rasio antara koleksi multimedia dengan total 
koleksi digital, 7) Rasio antara tingkat akses koleksi digital dengan koleksi non digital.

c) Standarisasi pengumpulan konten digital, yaitu berasal dari softcopy langsung dari penyusun atau hasil scanning dan kelengkapan dan kesesuaian isi.

d) Standarisasi proses scanning (sudah dibahas pada bagian design perpustakaan digital). 5 . Standarisasi inisial dari sub unit organisasi maupun inisial jenis koleksi. Contoh: UPT1 = Unit Pelaksana Teknis di Kalimantan Timur

e) Standarisasi isi file digital (meliputi isi dan tingkat akses) Contoh: Isi file adalah lengkap, tetapi yang dapat diakses hanya sampul, kata pengantar, keterangan penerbit, daftar isi, abstrak, lembar pengesahan, kesimpulan/saran, dan daftar pustaka. Dengan demikian diperlukan file digital yang terpisahpisah untuk setiap bab. Hal ini akan memudahkan dalam pengaturan tingkat akses serta mempercepat proses akses.

f) Standarisasi tata nama file, folder, dan basis data digital Contoh: D2009sby = Folder yang berisi file-file per bab dari Disertasi tahun 2009 yang disusun oleh Susilo Bambang Yudoyono D2009sby0 = File Sampul sampai dengan daftar isi dari Disertasi tahun 2009 yang disusun oleh Susilo Bambang Yudoyono.
D2009sby1 = File Bab 1 dari Disertasi tahun 2009 yang disusun oleh Susilo Bambang Yudoyono. LP2008rko = Folder yang berisi file-file dari Laporan Penelitian tahun 2008 yang disusun oleh Rita Komalasari.

g) Standarisasi keamanan file digital 1) Dokumen file pdf adobe image tidak dapat copy paste 2) Security system pada file adobe pdf a. Tidak dapat diprint untuk halaman atau file tertentu atau dapat diprint dengan resolusi rendah $b$. Dipasang password untuk file adobe pdf c. Watermark identity 3) Termasuk standarisasi untuk backup data 9. Standarisasi peminjaman koleksi digital Proses peminjaman koleksi digital dapat dilakukan untuk koleksi yang mempunyai hak cipta seperti buku, dengan sistem keamanan dokumen yang maksimal, dimana hanya bisa dibaca dan tidak dapat dicopy ataupun di edit, serta setelah jangka waktu peminjaman terlewati maka file digital tersebut akan rusak dengan sendirinya. Jumlah peminjam (dalam hal ini sama dengan jumlah eksemplar untuk koleksi tercetak) bisa diatur secara otomatis, begitu pula dengan jumlah pinjaman per pengguna.

h) Standar pertukaran data misalnya adalah Z 39.50 oleh the American National Standards Institute yang merupakan standar pertukaran data katalog melalui internet, 
disamping itu juga the Dublin

Core Metadata yang berisi 15 elemen yang telah disetujui dalam suatu pertemuan International di Dublin, Ohio, ke 15 elemen tersebut adalah: title, creator, subject, descriptions, publisher, constributor, date, type, format, identifier, source, language, relation, coverage dan rights.

\subsection{Proses Perpustakaan Digital}

Suryandari

(2007:10)

mengungkapkan proses digitalisasi yang dibedakan menjadi tiga kegiatan utama, yaitu:

a) Scanning, yaitu proses memindai (men-scan) dokumen dalam bentuk cetak dan mengubahnya ke dalam bentuk berkas digital. Berkas yang dihasilkan dalam contoh ini adalah berkas PDF.

b) Editing, adalah proses mengolah berkas PDF di dalam komputer dengan cara memberikan password, watermark, catatan kaki, daftar isi, hyperlink, dan sebagainya. Kebijakan mengenai hal-hal apa saja yang perlu diedit dan dilingdungi di dalam berkas tersebut disesuaikan dengan kebijakan yang telah ditetapkan perpustakaan. Proses OCR (Optical Character Recognition) dikategorikan pula ke dalam pross editing. OCR adalah sebuah proses yang mengubah gambar menjadi teks. Sebagai contoh, jika kita memindai sebuah halaman abstrak tesis, maka akan dihasilkan sebuah berkas PDF dalam bentuk gambar. Artinya, berkas tersebut tidak dapat dioleh dengan program pengolahan kata.

c) Uploading, adalah proses pengisian (input) metadata dan meng-upload berkas dokumen tersebut ke digital library. Berkas yang di-upload adalah berkas PDF yang berisi full text karya akhir dari mulai halaman judul hingga lampiran, yang telah melalui proses editing.

Di bagian akhir, ada dua buah server. Server pertama yaitu sebuah server yang berhubungan dengan intranet, berisi seluruh metadata dan full text karya akhir yang dapat diakses oleh seluruh pengguna di dalam Local Area Network (LAN) perpustakaan yang bersangkutan. Sedangkan server kedua adalah sebuah server yang terhubung ke internet, berisi metadata dan abstrak karya tersebut. Pemisahan kedua server ini bertujuan untuk keamanan data. Dengan demikian, full text sebuah karya hanya dapat diakses dari LAN, sedangkan melalui internet, sebuah karya hanya dapat diakses abstraknya saja.

Menurut Listyorini dan Iqbal (2015:118) proses digitasi perpustakaan menggunakan metode pengembangan sistem yang menggunakan waterfall. Waterfall sebagai pendekatan klasik dalam daur hidup pengembangan sistem yaitu : 1) perancangan (pemilihan 
buku/jurnal/prosiding/e-book); scanning jika referensi masih berupa cetakan; 3) proses penyeragaman nama referensi. Sedangkan menurut Astuti dan Nurasmi (2013:38) mengatakan persiapan yang perlu dilakukan dalam pembuatan digital meliputi:

1. perangkat

keras

(komputer,scanner);

2. perangkat

(Vistascan/Hpscan,

lunak

Acrobat, MsWord).

Langkah-langkah

proses

digitalisasi diatas dapat dijadikan referensi untuk pembanguan sistem perpustakaan digital yang ada di IAIN Batusangkar. Program yang digunakan oleh perpustakaan IAIN Batusangkar dalam membangun perpustakaan digital adalah program open source dengan aplikasi ZiShof E-library.

Aplikasi yang relatif lengkap (enterprise) dan terpadu/terintegrasi yang membantu dalam pengelolaan/ pengadministrasian berbagai aktifitas pada perpustakaan" ungkap (Indra: 25 Juni 2016). Kegiatan yang terintegrasi disini adalah terhubung dengan aplikasi e-campus IAIN Batusangkar dalam bentuk jaringan dengan kegiatan perpustakaan (Perencanaan dan pengadaan, pendataan, peminjaman, pengembalian, dan pelaporan). Berdasarkan hal diatas Tim ICT mengembangkan desain perpustakaan menjadi sistem ECampus Perpustakaan IAIN Batusangkar yang berbasis digital.

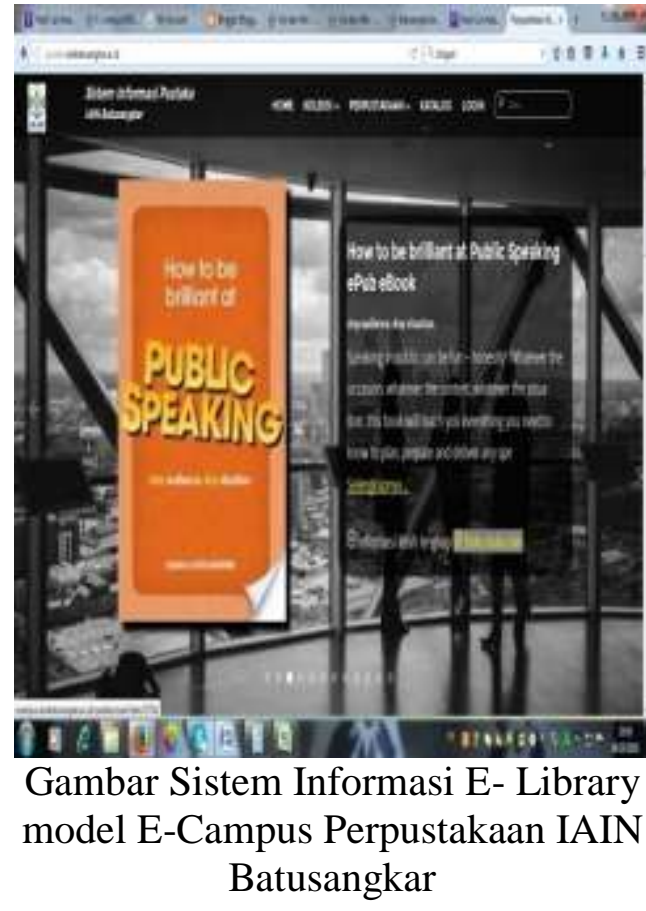

2.3 Keuntungan Pengembangan sistem e-Library perpustakaan digital

Perpustakaan digital menurut Gatot Subrata (2009:7) memiliki beberapa keunggulan diantaranya adalah:

1) Long Distance service, artinya dengan perpustakaan digital, pengguna pustaka bisa menikmati layanan sepuasnya, kapanpun dan dimanapun

2) Akses yang mudah. Akses perpustakaan digital lebih mudah dibanding dengan perpustakaan konvensional, karena pengguna tidak perlu dipusingkan dengan mancari katalog dengan waktu yang lama

3) Murah (cost efective), perpustakaan digital tidak memerlukan banyak biaya. 
Mendigitalkan koleksi perpustakaan lebih murah dibandingkan dengan membeli buku

4) Mencegah duplikasi atau plagiat. Perpustakaan digital lebih "aman", sehingga tidak akan mudah untuk plagiat. Bila menyimpan koleksi perpustakaan menggunakan format pdf, koleksi perpustakaan hanya bisa dibaca oleh pengguna pustaka, tanpa bisa mengeditnya.

5) Publikasi karya secara global. Dengan adanya perpustakaan digital, karya-karya dapat dipublikasikan secara global ke seluruh dunia dengan bantuan internet.

Pengembangan sistem $e$ library melalui perpustakaan digital ini sesuai dengan penelitian sebelumnya oleh Ibrahim (2011:C.92) yang menyatakan metode Prototying pada Fasilkom Usri akan menghasilkan perangkat lunak perpustakaan berbasis teknologi informasi untuk meningkatkan kinerja layanan perpustakaan dan mewujudkan perpustakaan ideal berbasis digital. Penelitian Dana (2008:8) juga mengungkapkan penerapan perpustakaan digital atau Digital Library yang dirancang dan dikembangkan dengan menggunakan MySqlServer 2000 dan Microsoft Visual Studio pada Universitas Atmajaya Yogyakarta dapat meningkatkan kualitas dan kecepatan proses layanan pada pengguna perpustakaan, sehingga dapat memperlancar proses belajar mengajar di lingkungan kampus. Selain itu sistem ini dapat membantu manajemen perpustakaan serta dapat meningkatkan efektifitas dan efisiensi pengoperasional perpustakaan.

\section{METODE PENELITIAN DAN PEMBAHASAN}

$\begin{array}{rlr}\text { Digital } & \text { Library } & \text { atau } \\ \text { perpustakaan } & \text { digital } & \text { pada }\end{array}$
perpustakaan dibangun/ dirancang dengan menggunakan metode cepat (Fast Methodology) yang terdiri dari 6 fase (Zainal,2005) yaitu :
a. requirement analysis phase,
b. decision analysis,
c. design phase,
d. construction phase,
e. implementation phase,
f. operation and support phase.

Pada fase requirement analysis phase, dilakukan kegiatan analisis mengenai semua keutuhan yang akan dikembangkan perpustakaan digital serta modulmodul apa saja yang akan dibuat di dalamnya. Fase kedua yaitu decision analysis phase, dilakukan kegiatan yang menyangkut keputusan yang akan diambil dalam menentukan sistem operasi, basis data, bahasa pemrograman dan teknologi yang digunakan dalam pengembangan sistem perpustakaan digital. pada tahap ini perpustakaan IAIN Batusangkar menggunakan 
program Aplikasi Zishoft E-Campus

yang terhubung secara langusng dengan user akademik mahasiswa itu sendiri. Langkah selanjutnya yakni mendesain dan mengkonstruksikan serta mengimplementasikan sistem yang dibangun.

\begin{tabular}{lll}
\multicolumn{2}{c}{ Langkah yang dilakukan } \\
adalah mendesain rencangan \\
arsitektur & sistem, basis data dan \\
rancangan interface. Ini adalah fase
\end{tabular}
design phase. Fase keempat yaitu construction phase, kegiatan yang dilakukan adalah perancangan sistem perpustakaan digital yang telah dibuat pada fase sebelumnya akan diimlementasikan menjadi sebuah program. Dengan kata lain fase ini terdapat kegiatan baik untuk implementasi server, back office, maupu front office.

Fase selanjutnya yaitu implementation phase, kegiatannya adalah pengujian terhadap sistem yang dibuat yang telah diimplementasikan baik untuk implementasi server, back office, maupun front office. Adapun tujuannya adalah untuk mengetahui apakah sistem perpustakaan digital yang telah dibuat memenuhi kebutuhan yang ada pada penggunanya. Pada fase training phase, kegiatan yang dilakukan adalah training atau pelatihan pada para staf, operator, teknisi, dan administrator yang akan menangani sistem perpustakaan digital tersebut.

Fase terakhir yaitu operation and support phase. Kegiatan yang dilakukan pada fase ini adalah pengoperasin sistem perpustakaan digital serta dilakukan perbaikan masalah yang timbul serta memelihara sistem yang telah beroperasi. Dengan langkah-langkah ini, maka diharapkan sistem perpustakaan digital yang dibangun dapat berjalan sesuai dengan yang telah dikehendaki. Program yang digunakan oleh perpustakaan Institut Agama Islam Negeri Batusangkar dalam membangun perpustakaan digital adalah program open source dengan aplikasi ZiSoft yang kemudian dikembangkan dan didesain oleh tim ICT perpustakaan dan ICT IAIN Batusangkar.

Digitalisasi koleksi perpustakaan memerlukan biaya yang tidak sedikit karena untuk mendigitalisasi sebuah dokumen dari bentuk cetak ke dalam bentuk digital diperlukan beberapa tahap. Pertama scanning, yaitu merubah dari bentuk cetak ke bentuk digital. Kedua editing, yaitu mengedit data yang telah diubah ke dalam bentuk digital untuk kemudian siap disajikan kepada pengguna. Dalam proses editing juga diberikan keamanan sehingga tidak dapat dirubah oleh pengguna, seperti contoh pada koleksi skripsi, tesis dan disertasi perlu diberikan keamanan agar copyright tetap ada pada si penulis.

Perlu juga komputer yang mempunyai performa yang cukup tinggi sebagai sarana untuk menyimpan serta melayani pengguna dalam mengakses koleksi digital. 
Untuk programnya digunakan Visual Studio .Net dan pada basis datanya menggunakan My SQL server 2000. Sehingga dengan adanya program ini diharapkan kendala yang dihadapi oleh Perpustakaan yaitu lokasi kampus I, dan II, yang berbeda dapat diatasi. Dengan demikian petugas bagian sirkulasi dapat mengetahui buku yang dipinjam oleh seorang mahasiswa, baik buku tersebut ada di lokasi perpustakaan kampus I, dan II. Bagi pengguna bila sistem ini sudah dioperasikan secara maksimal akan dapat mengetahui status buku, apakah buku tersebut sedang dipinjam atau bisa dipinjam. Sedang absensi pegawai berfungsi untuk mengetahui waktu kehadiran dan pulang seorang pegawai, sehingga dapat dipantau.

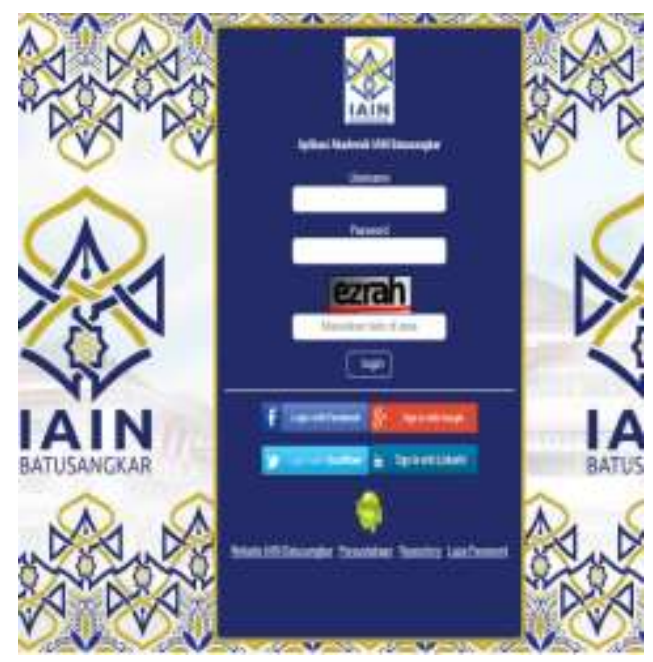

Gambar Sistem Informasi E-Campus IAIN Batusangkar

$\begin{array}{lcr}\text { Pada gambar } & \text { tersebut } \\ \text { memperlihatkan } & \text { bahwa } & \text { Digital } \\ \text { Library ini } & \text { dirancang } & \text { dan }\end{array}$ dikembangkan dengan menggunakan MySqlServer 2000 dan Microsoft Visual Studio.Net.Serta tools yang membantu dalam perancangan gambar yaitu AdobePhotoshop CS2. Digital Library ini dapat diakses bagi pengguna yang memiliki koneksi internet, karena aplikasi Digital Library ini berjalan dalam jaringan internet. aplikasi ini terhubung secara langsung dengan websiteIAIN Batusangkar, perpustakaan, akademik , mahasiswa, dosen dan pegawai IAIN Batusangkar. keberadaan aplikasi ini dapat mendukung proses perkuliahan secara langsung yang dikelola oleh server utama pada Teknologi Informasi dan Pangkalan Data (TIPD).

Aplikasi ini juga memberikan gambaran kepada akun masingmasing atas histori peminjaman dan pengembalian buku yang telah dilakukan.

Aplikasi ini juga digunakan untuk memberikan pengumuman/ informasi-informasi akademik secara langsung kepada mahasiswa yang mengakses akun e-campus mereka masing-masing.

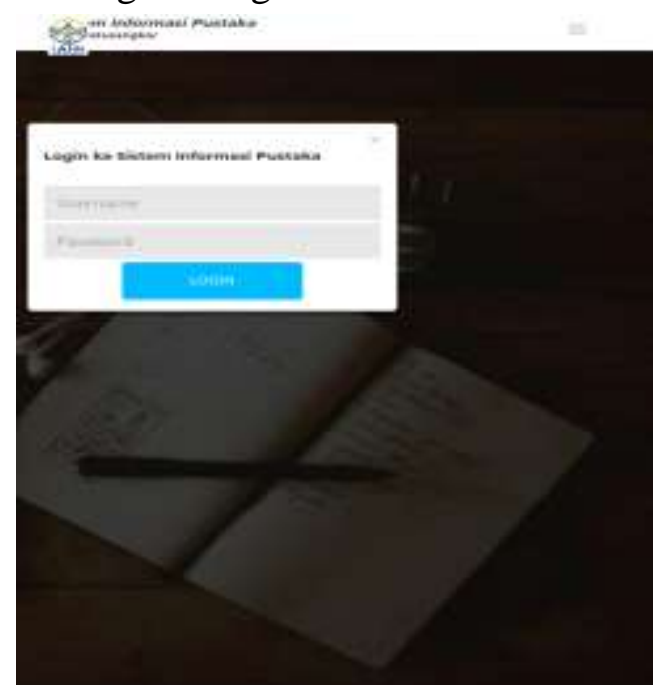

Gambar Log In Sistem Informasi Pustaka IAIN Batusangkar 
Pada Gambar ini dapat dilihat tampilan awal dari Digital Library. Dimana pada tampilan awal ini pengguna harus memasukkan nama user dan password yang sesuai dengan nomor induk mahasiswa (NIM) setelah mahasiswa terdaftar sebagai mahasiswa IAIN Batusangkar.

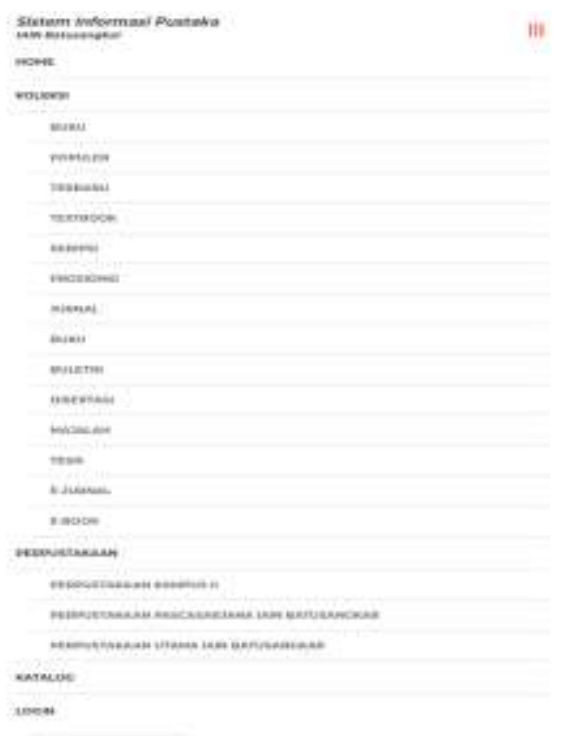

Gambar Sistem Informasi Pustaka IAIN Batusangkar

Pada Gambar ini dapat dilihat tampilan Home dari Digital Library IAIN Batusangkar. Dimana pada tampilan awal ini pengguna dapat mengakses sesuai dengan kebutuhan dengan memilih menu bar yang dia inginkan. pada tampilan home ini menyajikan tab bar seperti: koleksi, catalog, perpustakaan dll. pada tampila iini juga disediakan menu langsung pencarian yang memudahkan pengunjung web untuk mencari kebutuhannya

\section{KESIMPULAN DAN SARAN}

Perpustakaan bukanlah lembaga yang memberikan pelayanan tertutup namun sebuah lembaga ataupun bangunan yang mampu memberikan data/ informasi yang luas yang dapat diakses dari segala penjuru oleh siapa saja tanpa harus mendatangi lokasi perpustakaan tersebut. Fenomena pobia individu, jarak lingkungan yang jauh, dan kebutuhan sosial akan informasi yang mudah diakses akan dapat teratasi dengan adanya pengembangan sistem e-library dengan perpustakaan berbasis digital. Kecanggihan teknologi dengan menghadirkan perpustakaan digital menjawab kebutuhan kepada pengguna pustaka dengan sistem layanan melalui internet, akses informasi dan data yang cepat tanpa harus antrian dan memakan waktu lama.

Transformasi perpustakaan IAIN Batusangkar yang terjadi saat ini merubah banyak hal baik yang berkaitan langsung maupun tidak langsung dengan perpustakaan, seperti pengguna pustaka, pustakawan sebagai pengelola dan sistem informasi sebagai alat dalam melancarkan berbagai kegiatan pada perpustakaan IAIN Batusangkar.

Keuntungan menggunakan elibray digital perpustakaan dengan pemanfaatan teknologi informasi sudah banyak dirasakan meskipun masih terkendala dengan berbagai persoalan lain seperti, Manajemen perpustakaan sendiri,sarana dan 
prasarana, SDM/ perencanaan akan kebutuhan pustakawan yang mendukung secara optimal pada perpustakaan. Banyaknya persiapan proses yang dilalui untuk suatu kemajuan perpustakaan dimasa depan saya menyarankan agar pemerintah memberikan perhatian khusus pada perpustakaan berkaitan dengan kelengkapan sarana-prasarana yang optimal yang mampu menunjang perpustakaan untuk menjadi perpustakaan digitalisasi dan jaringan koneksi inernet yang tersebar keseluruh daerah agar koleksi dapat diakses menyentuh seluruh lapisan masyarakat indonesia khususnya.

\section{REFERENSI}

Astuti, Yuli dan Nurasmi. 2013. Pengembangan Perpustakaan Digital Universitas Riau Dengan Program Library Management Sistem (SLIMS). Jurnal Gema Pustskawan Vo. 1 No. 1. Mei 2013. Peknbaru, Riau: Perpustakaan UNRI.

Dana, Timotius., Desi Herlina Samosir dkk. 2008. Pengembangan Digital Library Perpustakaan Universitas Atmajaya Yogyakarta. Seminar Nasional Informatika 24 Mei 2008. Jurusan Teknik Informatika Fakultas Teknologi Industri Universitas Atmajaya Yogyakarta: Yogyakarta.

Ibrahim, Ali., Afrina, Mira. 2011. Pengembangan Model Perpustakaan Berbasis Teknologi Informasi untuk Meningkatkan Kinerja Layanan Perpustakaan dan Mewujudkan
Perpustakaan Ideal Berbasis Digital di Dasilkom Unsri. KNTIA. Universitas Sriwijaya.

Indra, Gusman. 2016. Workshop/ Sosialisasi Aplikasi E-Campus Perpustakaan IAIN Batusangkar. Batusangkar: IAIN Batusangkar. 13 Mei 2016 Ruang Pertemuan Dosen Gd K lantai. 4

Jie Sun, Bao Zhong Yuan. 2012. Development and Characteristic Of Digital Library as a Library Branch. Scivrse ScienceDirect Procedia IERI 2 (2012) 12-17 International Conference on Future Computer Supported Education.

Komalasari, Rita. 2014. Materi Pokok Manajemen Perpustakaan Cet.14;Ed.1. Tanggerang Selatan: Universitas Terbuka

Listyorini, Tri dan Iqbal, Mohammad. 2015. Pengembangan Digital Library Berbasis Web Responsive ( Studi Kasus Fakultas Teknik Universitas Muria Kudus). Kudus : Konferensi Nasional Informatika (KNIF)2015.

Maaruf, Sugeng. 2009. Studi Eksperimen Relatif Recall dan Precision Pada Temu Kembali Informasi Aplikasi IBRA di Perpustakaan Umum Kabupaten Bantul. Yogyakarta: UIN Sunan Kalijaga Yogyakarta.

Sismanto. 2008. Manajemen Perpustakaan Digital. Modul Universitas Terbuka: Tanggerang Selatan.

Siswadi, Irman. 2009. Perpustakaan Sebagai Mata Rantai Komunikasi Ilmiah (Scholary 
Communication). Visi Pustaka, Vol. 11 No. 1 April 2009: 1-9.

Subrata, Gatot. 2009. Perpustakaan Digital. Pustakawan Perpustakaan UM : Malang

Suryandari, Ari. 2007. Aspek Manajemen Perpustakaan Digital.Jakarta : CV Sagung Seto.

Susanto, Setyo Edy. 2010. Desain dan Standar Perpustakaan Digital. Jurnal Pustakawan Indonesia Volume 10 No. 2. Sekretaris Perpustakaan IPB. 8 November 2010.

Syamsudin, Rizal. 2013. Evaluasi Efektivitas Temu Kembali Pada System Digital Library Di Perpustakaan UIN Sunan Kalijaga Yogyakarta.
Yogyakarta: UIN Sunan Kalijaga Yogyakarta.

Undang-Undang Republik Indonesia Nomor 43 tahun 2007 tentang Perpustakaan.

ViVid, Rizqy Manurung. 2014. Perkembangan Tekhnologi Informasi Perpustakaan Menggunakan Digital Library System dan Kaitannya dengan Konsep Library 3.0. Jurnal Iqra' Volume 08 No. 2. Oktober 2014.

Wawancara mahasiswa andri PAI tanggal 11 oktober 2016

Yuadi, Imam. 2007. Perpustakaan Digital Paradigma, Konsep dan Teknologi Informasi yang digunakan. Jurnal Jurusan Ilmu Informasi dan Perpustakaan FISIP Unair: Surabaya 